\title{
Aisthesis
}

Firenze University Press

www.fupress.com/aisthesis

OPEN ACCESS

Citation: A.C. Sabatino (2021) Vaccine Selfie. The double face of self-representation in Covid-19 era. Aisthesis 14(1): 101-108. doi: 10.36253/Aisthesis- 12812

Copyright: (c) 2021 A.C. Sabatino. This is an open access, peer-reviewed article published by Firenze University Press (http://www.fupress.com/aisthesis) and distributed under the terms of the Creative Commons Attribution License, which permits unrestricted use, distribution, and reproduction in any medium, provided the original author and source are credited.

Data Availability Statement: All relevant data are within the paper and its Supporting Information files.

Competing Interests: The authors have declared that no competing interests exist.

\section{Vaccine Selfie. The double face of self- representation in Covid-19 era}

\author{
Anna Chiara Sabatino \\ Università di Salerno \\ asabatino@unisa.it
}

\begin{abstract}
If at its beginnings the Selfie was interpreted as an expression of the narcissism of contemporary culture, at the time of Covid-19 not only does it become the ordinary mask of the show performed on the stage of social networks, but it acquires the power to act on the social body. The Selfie, therefore, can be characterized as an iconic two-faced act with contradictory and ambiguous intentions and outcomes. The contribution examines the case of the Vaccine Selfie, in this particularly emblematic sense.
\end{abstract}

Keywords: Covid-19, Self-representation, Image, Social body.

\section{SELF-REPRESENTATIONAL FORMS AND THEIR BODIES}

In the contemporary pandemic world, self-representational processes are almost inevitably involved in everyday and personal storytelling (Busetta [2019]; Eckel, Ruchatz, Wirth [2018]). At the time of the Covid-19 the user of digital media - first bricoleur and then remixer - has been frequently summoned to a constant mediatization through self-portrayal narrative forms (Bellour [2002]), which allowed more and more frequently to escape the domestic and claustrophobic reality due to lockdown contingencies. The amateurisation of self-representational experience, in this sense, has been inevitable. Contemporary self-narratives are, in fact, literally in the hands of the everyday user who tells her/his own everyday life stories using the equipment mobility and its almost unconditional availability.

For my theoretical proposal regarding self-representative forms in the pandemic era, the role of the face is central, starting from the Selfies that proliferate on the screens of each device. If the image of our face is nothing more than an instrument we use to "play" building our identity in an Goffmanian relationship between the face and the mask we wear on the stage of public life, the Selfie is first of all 
a conversational image (Gunthert [2014]), actually a networked one - an assemblage (Hess [2015]). In fact, as both social and technical object, when lockdown inhibited physical proximity, the networked mask of the Selfie acted on the pandemic stage as one of the few relational tools and practice (Gómez Cruz, Thornham [2015]) that include the broadcaster ego into the picture and allow to "make present" the subject of the representation through technological mediation, often asking for an emotional reaction also with an act of appreciation suck "like". In short, a Selfie is at the same time representation (a photo) and presentation (a performance), as well as a conversational iconic object and a materially and affectively entangled picture.

In the contemporary variant of the "Narcissism epidemic" - and far beyond a reductionist generational reading of the 2000s, however soon criticized (Twenge [2006, 2009]) -, a ménage à trois is established between the subject, its reflection and its eco (Santangelo [2020]). The Selfies posted on social networks are in fact echoes of the identity of those who produce them, heuristic outcomes of a relational and dialogical practice of self-design or self-branding through a sharing to be recognized, appreciated, but even only seen and experienced through the web, that during the hardest phases of lockdown often seemed to be the only socially habitable place.

Not only, therefore, a proliferation of the Selfies with protective masks, double cultural and historically contingent ones (Dynel [2021]), can be recognised, but also of the videocall images, closeups or half-length framings where we are called to show ourselves, for work or pleasure, in the need to occupy space that is virtual, yet material, since the complex procedural gestures that access to devices and platforms implies (Zimmermann [2020]).

Consequently, the user pursues the self-representational act first of all thanks to its productive gestures, of which the self-representational form of the Selfie constitutively carries the traces. Far from the concept of a representation that benefits the transfer of reality from the object to its repro- duction thanks to the mechanical process initiated by the analogical medium, the indexical logic that characterizes the Selfie is no more tributary of a reality to which it ontologically refers. Such process is, rather, a deictic and agentive regime within which the producer is inscribed and materially operates through a connective performance (Frosh [2015]).

Such performance can only take place thanks to a particular medium, the body, exquisitely amateur and committed to "the passion of the material" (Sobchack [2004]) that necessarily goes through a technological device: as Maya Deren (1965) wrote in the Sixties, the great advantage that the amateur has over the professionals consists precisely in its mobile body, its imaginative mind and freedom of choice to use both to making films.

The body itself is therefore a living and technological medium, since it allows us to acquire, archive, retrieve and transform images through mnemonic, creative and productive processes that are both externalized and embedded. Seen as technical and technological objects that emerge from the involvement of a subject always individually embodied, enworlded and entangled, the media are to be understood as potential, complex and ambiguous acts and processes of subjectivation. In this sense, the miniaturization of technological tools, allowing the proliferation of a deeply artisanal filmic practice, hands over to the amauthor (Sabatino [2020]) the chance to create their own narratives through amateur filmmaking (Rascaroli, Young, Monahan [2014]), which requires above all bodily and embodied narrative acts. Selfies are also clearly bodily images, as they are not only images of our bodies but also images of the body behind the camera establishing its relation to the world (Mcdougall [2006]).

Such productive dynamics are crucial for the iconic amateur productions in time of Covid-19. As outcome of contextual interactions, bodily movements and technical gestures as conveyed by media innervating the daily experience of self in the ordinary world, in the pandemic era the selfrepresentation becomes a material act to reclaim 
a relational, narrative and narrated Self, of which social distancing has deprived us during the lockdown. It is exactly through such self-representative dimension that images provide access to certain spheres of the everyday life, otherwise inhibited in such circumstances.

\section{MATERIAL (ACTING) SELFIES}

During the days of the Covid-19, the process that produces the transition from immaterial to material in amateur self-representations acquires a renewed relevance, which it is worth reflecting upon.

When the iconic object depicts its own creator, as in the case of the audiovisual or photographic self-portrait, the contact of the iconic subject with the produced object inevitably leaves traces of the representative act itself, following the indexical logic I mentioned earlier ${ }^{1}$.

Selfie's productive gestures are emblematic of the delicate relationship that is activated between the materiality and the immateriality of self-representation, especially in the embodied relationship of the producer with their own image (Warfield [2018]). The amateurs who produce a digital image of themselves, on the one hand, bear the responsibility of their own technical and declarative gesture; on the other, in a more unreflective and expressive way, they call in their own body and flesh, since it refers to what they see, feel and perceive while they are flesh and blood in the place of the event (Fontanille [2006]).

The digital photographic self-image is therefore unthinkable outside the act that makes it exist, and therefore inseparable from the context and its referential situation much more than analog photography (Dubois [1983]), for which the self-representation was not feasible as contemporary prosthetic technology nowadays allows (Cati [2011]). As such, the amateur audiovisual and photographic gestures acquire exclusively performative characteristics, transforming them-

${ }^{1}$ I recall here the classic phenomenological derived division between Bildding, Bildobjeckt, and Bildsujet. selves through and within the reality of the media where they are contextualized and used, not only through the gaze, but also through technical and bodily involvement.

Integrated as it is inside portable devices such as smartphones, the camera works as an extension of the limb of the amateur operator (Giusti [2019]): as an embodied device, it generates an image where the presence of the author is clearly visible thanks to aesthetic-formal characteristics (the blurring of forms, out of focus traits and other stylistic choices) typical of the cine-amateur practice. Thus, this authorship seems to be evidence and symptom of the physical and material - but also social, ethnic, gender and therefore "immaterial" (Carnevali [2012], Blackman [2012]) - inscription of the subjects directly involved within the selfportrayal device, starting from the act to turn the screen towards own face and begin recording.

The Selfie is then an iconic digital object that preserves and crystallizes the authorial trait of the self-portrait, both in its iconographic subject and in the material trace of the gestural and technological production. The practice of Selfie, therefore, "not only composes technicity and embodiment in the moment of image production; it also constitutes a deictic movement of the body that draws attention to the immediate context of image viewing and to the activity of a viewer» (Frosh [2015]: 1615). The act of framing, zooming and selecting the frame, of touching the device screen to activate the front camera and start or stop the recording, are the founding elements of the connective performance that involves and "concerns" the operator (Ibid.).

This indexical circularity concerning the amateur self-narrative forms concretely binds the representation to its productive subject, to its technical and medial performance and its object. Configuring itself as an index and expression of the will and creative act of its agent, the digital photographic or audiovisual Selfie constitutes an amateur artifact, both allographic and autographic ${ }^{2}$,

\footnotetext{
${ }^{2}$ For a first approach to this question, that lies outside
} this work, see D’Cruz, Magnus (2014). 
whose identity can only depend on the technical and existential conditions of its history and on the material immanence of its object, bearer of social, cultural, ethnic and gender traces of its maker.

As it can be easily noted from the countless self-representative videos that populate everyday life, starting from the digital meetings that allows work and school activities to be pursued, the audiovisual Selfies describe the identity of their authors not only as explicit representations of the subject but also through additional significant elements. I am thinking of videocall backgrounds, rearranged as occasional sets, selectable from a library of available locations or predetermined filters, but also of para-operational technical gestures in order to adjust the framing and the lighting.

But this issue cannot be considered exclusively private. Just like the Infodemic outbreaks of links, posts, tweets, infographics, photos and memes that describe, comment on and inform the inhabitants of the global infosphere about the Coronavirus, the hyper self-representation on social networks seems to keep following the trend - initiated during the first lockdown - of inhabiting the online more than the offline. Due to the emergency situation, the online surfing in fact became a surviving tool to temporary replace the reality and ordinary life with a bubble of contents of their own and about themselves.

Facing the iconic invasiveness and pervasiveness that cause infections harder to fight than information alone, the self-representative social network activities increasingly summon the users to narrative acts aimed at literally showing them to be there and assert their existence, but also their icon resistance.

If the Selfie has been wrongly interpreted as an expression of the narcissism side - sometimes as the pathological one - of the contemporary culture, in the Covid-19 era it becomes the ordinary wearable mask on the social networks stage, as well as on the daily life stage that occupies increasingly expanded virtual spaces.

In this sense, it can be considered a particular social act (Lefebvre [1947]) that the producer of the image, in the triple role of main character, author and spectator, realizes in an always situated and performative process, where the agentive connection is not arbitrary, but caused by the significance of the technological gesture at the origin of the self-image.

Given the correspondence and deictic circularity between the subject, the technological medium and the object of the representation, in the amateur self-narratives a particular form of iconic agency (Gell [1998]) takes place: it can activate a feedback between production, narration and fruition that is not always effective, but rather unpredictable.

In the self-representational logic of the Selfie, it seems to me that a performative "profanation" (Casetti [2015]), never obvious and univocal, can be recognized, where the relationship between subject and sense, theoretically produced and predetermined by the soft power of the medial device, is medially shaped and influenced.

Indeed: thus complex relationship between the subject of the Selfie and the meaning created by the sharing of experience through the image can be ambivalent and ambiguous, precisely because of the hyper contextualization of production and the indeterminacy of the fruitional expectations.

In fact, the indexical and symbolic circularity between the producer, the medium and the context of fruition always operates bidirectionally and relationally through a social feedback generated in the circulation and consumption of the image far beyond the intentionality of the creators.

From the image to the situation in which it is realized, from the subject to the anonymous and indeterminate recipient to whom it is addressed, and vice versa, a Selfie could be the product of an individual who performs and stages, illustrates and shows oneself, but also of a subject who uses the device in order to return an image caged in one genre to another use, or to search for a meaning not only shared but also collective. It could be, in short, an image that responds to an ethical instance rather than a narcissistic aestheticization of itself. It could. 


\section{“I WAS THERE, I DID IT": VACCINE SELFIE}

According to the argument carried out so far, it is possible to state that the contextual self-representation of the Selfie activates complex narrative processualities, which involve the body and are made possible by its gestures, which are both condition of technical possibility and subjects of such self-representation. In the pandemic era, the Selfie provokes a particularly articulate and multiform social feedback, not linear nor easy to read, since the iconic agency is conveyed and reverberated by personal and institutional devices, by individual and shared social channels that show and tell the stories of the vaccination campaign progression.

The case of the photos that show the moment of the Covid-19 vaccine administration, a phenomenon now becoming viral due to the sharing on famous and ordinary people social profiles of in the act of inoculation, is truly emblematic. Defined a new social genre, by some news articles such as the New York Times ${ }^{3}$, the iconography of the Vaccine Selfie ${ }^{4}$ is historically reconstructed starting from the wellknown photo of Elvis Presley, getting vaccinated against poliomyelitis with the sleeve of the sweater up, smiling together with the doctor and the nurse who are inoculating the vaccine.

Strictly speaking, the image in question, soon re-mediated ${ }^{5}$, is not a real Selfie. The documentary images of politicians and celebrities in the act of getting vaccinated are recently becoming popular, especially because, as the New York Times writes, documenting with images "works".

\footnotetext{
${ }^{3}$ V. Friedman, Enter the Age of the Vaccine Selfie, New York Times, published Apr 1, 2021, url: https://www. nytimes.com/2021/04/01/style/vaccine-selfies.html. Cfr. H. Schwedel, Every Celebrity Vaccine Selfie, Ranked From Worst to Best, published Mar 22, 2021, url: https://slate. com/human-interest/2021/03/celebrity-vaccine-photosselfies-ranked.html.

${ }^{4}$ The Vaccine Selfie can be associated with the Hospital Glam subgenre as well, cfr. Tembeck (2016).

${ }^{5}$ M. P. Nocerino, Pompei, spunta unialtra opera di Nello Petrucci, Magazine Pragma, published Jan 4, 2021, url: https://magazinepragma.com/arte/pompei-spunta-unaltra-opera-di-nello-petrucci/
}

It works because the images themselves are involved in the vaccination campaign as awareness-raising tools, normalizers of a collective and global experience, often told with neutral and reassuring tones of positive empathy and social sympathy.

Some of these vaccine self-portraits are, on the contrary, real Selfies, such as the one of the designer Marc Jacobs, who posed with his unbuttoned shirt while getting vaccinated. Linguistically, the difference is glaring. If, as with Elvis, President Biden is photographed at the crucial moment by reporters who went to the vaccine location specifically to capture the scene, document it and spread the relative images, Marc Jacobs photographs himself in a mirror, as if to say "here I am. I'm doing it. Look at me".

In this sense, his celebrity face, well known and well recognizable in the photograph he took, acts in the self-representative device not only when he interpellatively intercepts his own reflection, the camera lens and the viewers' gaze, but also with a further purpose, in some unexpected and no less problematic ways, triggered by the image itself - in its linguistic and semantic composition.

The Selfie of the designer does not exclusively refer to the documentary, reportage and, dare I say, propagandistic function, nor does it linguistically take up the structural elements in the frame and in the point of view of the shot. Instead, it tells and clearly shows the involvement of the author and protagonist of the image, finally witnessing in the specific situation the indexical inscription of his body, here exposed together in its biological - mythologically universal, although historically strongly marked - vulnerability and in its singular stylization: embodiment and emplacement are here, as always, not only technologically and aesthetically, but also culturally and socially connoted.

The hyper contextualization, in this sense, is rich not only in fashion iconographic details, but also symbolic ones: next to the designer, an African American nurse, wearing a pink ribbon pin, a global symbol of the fight against AIDS, can 
here be seen as a powerful and debatable bridge between two epidemics very often forcibly juxtaposed under their respective imaginary. The power of the Vaccine Selfie seems to lie in the operator's intention to bring the viewer's gaze into the image and, at the same time, to summon the observer, the anonymous and ordinary recipient, in the extraordinariness and exemplarity of the situation and experience that are told in the Selfie from a factual, pragmatic and personal point of view.

What do the Vaccine Selfies want to tell us? Clearly "do it!", in a linguistically more effective and explicit way than the institutional and social awareness campaigns, although designed for the same purpose, managed to do. The greater Vaccine Selfie effectiveness is not only due to the explicitly amateur rhetoric, but also to the virality and engagement of millions of followers, who feel personally summoned by the celebrity they follow and admire. And they envy.

The Selfie and the act of Marc Jacobs are in fact avowedly social, but have different intentions, dimensions and purposes, revealing uses that are not univocal, perhaps actually incompatible. The Vaccine Selfie of Marc Jacobs is a self-contextual image, but the indexical agency that characterizes it activates multiple meanings: it is certainly a voluntary testimonial of the vaccination campaign - similar to other reportable and documentary images, although linguistically different -, but it is also an icon of the hyper-elitist world of fashion that becomes capable of intercepting, summoning and convincing the recipient to do the same by virtue of the social device functioning in which this image is inscribed.

The Marc Jacob's Vaccine Selfie activates an ambiguous pathemization process in the potentially moralized and socially adequate recipient, well disposed to accept shared and therefore collective emotions. In fact, the subject becomes aware of her/his own disturbance and however has difficulty in giving a unique name to her/his feelings and social sentiments: such meeting-clash between different passionate instances and components arouses conflicting feelings and emotional reactions.
So, "what do Vaccine Selfies really want?" The famous question to which Tom Mitchell has made us sensitive, not by chance discussing Uncle Tom's war manifesto ${ }^{6}$, is relevant here.

To answer the question, there would be necessary to build a typology and test a sample analysis of exemplary or paradigmatic cases; I cannot do it here and perhaps is not the most important thing. What matters, however, is to take note that during the new rituals of vaccination the many Selfies of ordinary people show us that the power of vaccination as a social device, producing behaviours and responses from the receptor of images, is doubled, amplified but also contradicted by the testimonial power of self-representation and its circulation in social network and on the internet.

The ethical virtue of the individual Selfie consists in actualizing a narrative virtuality made of infinite common stories, exemplifying a kind of collective, involuntary and participative self-portrait. Intended as echoes of identity and testimony of own selves, Selfies reach eyes and consciences as their producers and referents alone, however famous or powerful, could not do. In this sense, the Vaccine Selfie acquires a key role in the media pandemic scenario, placing itself in the social profiles of politicians and influencers no longer just as a "double face" of power or prestige, charismatic exemplariness, vanity or boast about a lifestyle, but also as an interpellation act, a call to action that many eyes can cross and listen.

In my opinion this is one of the most relevant implication of the question "what do Vaccine Selfie really want?" The agency of such a vulnerable self-image, a contemporary low intensity mythologeme (Ortoleva [2019]) of a shared humanity and biological life in the common extreme danger - regardless of gender, age, social, economic, ethnic and religious differences - also consists in producing a structural ambivalence of social feeling, putting into circulation and participating in it even beyond the intentions of its creators. A feeling that swings, as among the others Réné Girard (1961) and Elena Pulcini (2011) have

${ }^{6}$ See Mitchell (2005). 
shown, between sympathy and envy, harmony and resentment, in a manner similar to what happens in the mimetic desire and emulation that characterizes the most widespread and canonized Selfie practices?.

In fact, the Vaccine Selfie is configured as an iconic two-faced act. Primarily, it is a statement of subjectivity, performance and experience as body, technical gesture and testimony -, acting in a performative society that shifts the focus from the subject to the project (Han [2015]), from the singular life to the biological life as the object of the vaccination campaign. Secondly, Selfie is an iconic target of social envy, a harbinger of unprecedented forms of discrimination, resentments and stigmatizations on the body and on the social imagination.

It is therefore within and thanks to the social networks (Fuchs [2021]) that the Vaccine Selfie points to the viewers, including them first of all in a dialogue that apparently suspend the real social differences and involving them, at the same time, in a complex communicative and agentive emplacement, open to ambivalence, often unresolved and symptomatic of a latent or concealed contradiction.

Discursive interaction (Frosh [2015]), conversational image (Gunthert [2014]) and metalinguistic icon (Fontcuberta [2016]), the reflexogram of Marc Jacobs - among the many others that resemble it by genre and subject - is therefore the outcome of an amateur composition with conflicting effects, which seems to contradict its own meaning. If the Selfie wanted to ethically profane its productive and fruitional device by returning the image to a good common use, and if it was meant to be such a double antidote for the social body against the viral narcissism of social net-

\footnotetext{
${ }^{7} \mathrm{Cfr} . \mathrm{K}$. K. Thomason, It is totally normal to have vaccine envy right now, The Philadelphia Inquirer, published in Mar 22, 2021, url: https://www.inquirer.com/opinion/ commentary/covid-vaccine-distribution-envy-20210322. html; B. Huang, Why posting vaccines selfies on social media cause envy, frustration, Halifaxtoday, published in Feb 20, 2021, url: https://www.halifaxtoday.ca/coronavirus-covid-19-local-news/why-posting-vaccines-selfies-onsocial-media-cause-envy-frustration-3437389.
}

works during the pandemic of COVID-19, here it ends up reintroducing the evil into the remedy, the disease into the cure - envy and resentment into the image, infecting again the sense of community and compassion.

\section{REFERENCES}

Bellour, R., 2002: L'Entre-Images. Photo. Cinéma. Vidéo, Les Éditions de la Différence, Paris.

Blackman, L., 2012: Immaterial Bodies: Affect, Embodiment, Mediation, Sage, London-New York.

Busetta, L., 2019: L'autoritratto. Cinema e configurazione della soggettività, Mimesis, MilanoUdine.

Carnevali, B., 2012: Le apparenze sociali: Una filosofia del prestigio, Il mulino, Bologna.

Casetti, F., 2015: The Lumiere galaxy: Seven key words for the cinema to come, Columbia University Press, New York.

Cati, A., 2011: Figure del sé nel film di famiglia, "Fata Morgana", 15, pp. 35-44.

D'Cruz, J., Magnus, P.D., 2014: Are Digital Images Allographic?, "Journal of Aesthetics and Art Criticism”, 72 (4), pp. 417-427.

Deren, M., 1965: Amateur versus Professional, "Film Culture", 39, pp. 45-46.

Dynel, M., 2021: COVID-19 memes going viral: On the multiple multimodal voices behind face masks, "Discourse \& Society", 32(2), pp. 175195.

Dubois, P., 1983: L'acte photographique, Nathan/ Labor, Paris \& Bruxelles.

Eckel, J., Ruchatz, J., Wirth, S., 2018; Exploring the selfie. Historical, Theoretical, and Analytical Approaches to Digital Self-Photography, Palgrave Macmillan, Marburg.

Fontanille, J., 2006: Soma \& séma: figures du corps, Maisonneuve \& Larose, Paris.

Fontcuberta, J., 2016: La furia de las imágenes: notas sobre la postfotografía, Galaxia Gutenberg, Barcelona.

Frosh, P., 2015: The Gestural Image: The Selfie, Photography Theory and Kinesthetic Sociability, 
"International Journal of Communication", 9, pp. 1607-1628.

Fuchs, C., 2021: Social media: A critical introduction, SAGE publications Limited, London.

Girard, R., 1961: Mensonge romanesque et verite romantique, Grasset, Paris.

Giusti, S., 2019: Immagine-atto/immagine-arto: la fotografia come protesi tra performance e comportamento nellera della condivisione con le fotocamere in rete, "Mediascapes journal", 12, pp. 23-40.

Gómez Cruz, E., Thornham, H., 2015: Selfies beyond self-representation: the (theoretical) $f(r)$ ictions of a practice, "Journal of Aesthetics \& Culture", 7, 1, retrieved from: https://www. tandfonline.com/doi/citedby/10.3402/jac.v7.28 073? scroll=top\&needAccess $=$ true.

Gunthert, A., 2014: L'image conversationnelle. Les nouveaux usages de la photographie numérique, "Études photographiques", 31, retrieved from: https://journals.openedition.org/etudesphotographiques/3387.

Gunthert, A., 2015: La consécration du selfie, "Études photographiques" 32, retrieved from: http://journals.openedition.org/etudesphotographiques/3529.

Han, B. C., 2020: The burnout society, Stanford University Press, Redwood City.

Hess, A., 2015: Selfies: the selfie assemblage, "International journal of communication", 9, 18, pp. 1629-1646.

Lefebvre, H., 1947: Critique de la vie quotidienne, L'Arche, Paris.

Macdougall, D., 2006: The Corporeal Image: Film, Ethnography, and the Senses, Princeton University Press, Princeton.

Mitchell, W. J. T., 2005: What Do Pictures Want?: The Lives And Loves of Images, University of Chicago Press, Chicago.

Pulcini, E., 2011: Invidia: la passione triste, Il mulino, Bologna.

Ortoleva, P., 2019: Miti a bassa intensità. Racconti, media, vita quotidiana, Einaudi, Torino.

Rascaroli, L., Young, G., Monahan, B., (eds.), 2014: Amateur filmmaking: the home movie, the archive, the web, Bloomsbury Publishing, New York-London.
Sabatino, A.C., 2020: In materia di autoritratto amatoriale, "Esercizi filosofici", 15, 2, pp. 177191.

Santangelo, A., 2020: I narcisi mascherati, gli eroi e $n o i$, in Leone M. (ed.), Volti virali, Facets Digital Press, Open Access, pp. 39-66.

Sobchack, V., 2004: Carnal Thoughts: Embodiment and Moving Image Culture, University of California Press, Berkeley.

Tembeck, T., 2016: Selfies of ill health: online autopathographic photography and the dramaturgy of the everyday, "Social Media + Society", retrieved from http://sms.sagepub.com/content/2/1/2056305116641343.abstract.

Twenge, J. M., 2006: Generation Me. Why Today's Young Americans Are More Confident, Assertive, Entitled, and More Miserable Than Ever, Free Press, New York.

Twenge, J. M., Keith Campbell, W., (eds.), 2009: The Narcissism Epidemic. Living in the Age of Entitlement, Free Press, New York.

Warfield, K., 2018: Im(matter)ial Bodies: A Material and Affective Rethinking of Selfies for Digital Literacy Resources, "Language and Literacy", 20, 3, pp. 73-88.

Zimmermann, Y., 2020: Videoconferencing and the Uncanny Encounter with Oneself: Self-Reflexivity as Self-Monitoring 2.0, in Keidl, P. D., Melamed, L., Hediger, V., Somaini, A., (eds.), Pandemic Media: Preliminary Notes Toward an Inventory, Meson Press, Lüneburg, pp. 99-103. 